\title{
Estimation of Water Balance of Oyan Lake in the North West Region of Abeokuta, Nigeria
}

\author{
G. C. Ufoegbune ${ }^{1 *}$, H. O. Yusuf ${ }^{1}$, A. O. Eruola ${ }^{1}$ and J. A. Awomeso ${ }^{1}$ \\ ${ }^{1}$ Department of Water Resources Management and Agrometeorology, \\ University of Agriculture, Abeokuta, Nigeria
}

Research Article

Received $1^{\text {st }}$ February 2011

Accepted 11 ${ }^{\text {th }}$ February 2011

Online Ready $30^{\text {th }}$ March 2011

\section{ABSTRACT}

The paper presents results related to water balance of the Oyan Lake in the North West in Nigeria. The catchment covering an area of $9000 \mathrm{~km}^{2}$ includes a small dam called Oyan dam having an effective watershed area of $40 \mathrm{~km}^{2}$ with a gross storage of 270 million cubic meters. Hydrology of the area was characterized on the basis of land use, rainfall, temperature, evaporation, evapotranspiration, and runoff using meteorological data. Different methods like rainfall coefficient method is used to determine monthly distribution of rainfall including rainy and dry months; Penman method to calculate evaporation from the reservoir; Thornthwaite method and Thornthwaite water balance model to determine potential and actual evapotranspiration; and runoff coefficient method to estimate runoff. The catchment is characterized by one rainy season and two dry seasons during the year. The rainy season has five months duration and dry season seven months. The mean annual rainfall of the catchment is $1015.09 \mathrm{~mm}$, out of which rainy season accounts for $96.1 \%$ and the dry season for $3.9 \%$. The total annual water loss by evaporation from the reservoir is $1178.5 \mathrm{~mm}$. The mean annual actual evapotranspiration for the catchment is $899.3 \mathrm{~mm}$. The mean annual runoff generated from the catchment is estimated to be 822.2 million cubic meters. The amount of water that percolates into the ground in the catchment as groundwater is estimated to be about 219.9 million cubic meters, and the same at the reservoir site is 826.9 million cubic meters. The total amount of water which is actually available to recharge the groundwater within the catchment is 1046.8 million $\mathrm{m}^{3}$.

Keywords: Rainfall coefficient, evapotranspiration, infiltration, precipitation; 


\section{INTRODUCTION}

The demand of adequate water supply in developing countries is ever increasing with rapid population growth. Supplying adequate water with a reasonable quality is a major constraint in both local and regional planning for urban and rural areas. Domestic consumptions, industrial and irrigation activities mainly rely on water. In most cases, the demand for water exceeds the supply from various resources such as surface water and groundwater.

This, in many cases, is not due to lack of water resources but due to improper water resources utilization practices. The awareness for the critical and vital role of water resources in the growth and development of civilizations is not new. Many ancient civilizations prospered and flourished on account of and around the activities which emerged and were sustained by the available water resources (Prasad, 1982).

Meaningful planning to utilize and conserve water resources in any area should be based on the assessment of its available water resources. Assessment of available water resources can be done through a means of water balance analyses.

Thus, till the present time, there is lack of entirely satisfactory criteria and standards for water balance computations in different parts of the world. This situation is particularly true of Africa in general where the computation techniques used involves the application of the techniques which have been basically developed in the middle latitude countries, either in their original forms or in their modified forms, using data collected from parts of the continent.

There is no doubt that in recent times, greater interest than before has been created in the use of the water balance approach to the application of hydroclimatology to planning and development. The water balance models evaluates in simple term, the interactions of energy and water and provide a better approach than the application of individual parameters such as rainfall. The need to apply the water balance approach in hydrological studies has been realized for the past 20 or 30 years in West Africa in particular and Africa in general.

The water balance is an accounting of the inputs and outputs of water (Ritter, 2006). In other words, the study of the water balance is the application in hydrology of the principle of conservation of mass, often referred to as the continuity equation. This states that, for any arbitrary volume and during any period of time, the difference between total input and output will be balanced by the change of water storage within the volume. In general, therefore, use of a water-balance technique implies measurements of both storage and flux (rates of flow) of water. By appropriate selection of the volume and period of time for which the balance will be applied, some measurements may be eliminated (UNESCO, 1974).

The aim of the study is to estimate the water balance of Oyan Lake, with these specific objectives:

1. to determine the mean monthly rainfall,

2. to determine the seasonal pattern of rainfall,

3. to estimate the evaporation of water from Oyan reservoir

4. to determine the potential and actual evapotranspiration,

5. to evaluate the amount of surplus water, that is readily available for both infiltration and runoff and

6. to determine the amount of groundwater recharge available in the area. 
The results from this study will provide planners with valuable information useful for water resources management in the study area.

\section{MATERIALS AND METHODS}

\subsection{DESCRIPTION OF THE STUDY AREA}

Oyan reservoir dam, owned and operated by the Ogun-Osun River Basin Development Authority (O-ORBDA) was commissioned on 29th March, 1983.The lake is located on latitude $7^{\circ} 15^{\prime} \mathrm{N}$ and longitude $3^{\circ} 16^{\prime} \mathrm{E}$ at an elevation of $43.3 \mathrm{~m}$ above sea level on the confluence of Oyan and Ofiki rivers, both tributaries of Ogun river some 20 kilometers North West of Abeokuta, close to Badagry-Sokoto Highway, (O-ORBDA 1998; Ofoezie et al, 1991).

It has a catchment area of approximately $9,000 \mathrm{~km}^{2}$ within the southern climatic belt of Nigeria. The lake covers an area of 4,000 hectares (Fig. 1). It was designed to supply 525 million liters and 175 million liters of raw water per day to the Water Corporations at Lagos and Abeokuta respectively. It was also designed to provide water for the irrigation of about 3,000 ha Lower Ogun Irrigation Project under construction. In addition, it has the capacity to generate 9 mega watts of hydroelectric power for distribution to Abeokuta and its environs. The three turbines of 3.0 megawatts each have been installed since 1983 but have never been commissioned (put into use). The Authority also controls fishing activities on the reservoir. Before impoundment, there were thirteen villages on the Eastern and nine on the Western sides of the lake making a total of twenty-two (22) villages that were submerged with water. The authority thereafter established three settlement camps for the displaced communities: one on each bank of the lake in Ogun State and the third on the far end of the lake in Oyo State which were named Ibaro, Abule Titun and Igbo-Ora respectively (OORBDA, 1998). In all the locations, a total of 211 houses comprising 25 three bedroom and 186 two bedroom houses were constructed and allocated to the resettlers (Ofoezie et al, 1991). At present, there are other villages e.g., Apojola, Imala-odo and Akiro where some migratory fisher folks have been able to settle their families erecting palm fronds and thatched roofed houses as observed at Apojola and Akiro but using concrete blocks at Imala-Odo.

\subsection{DATA COLLECTION AND PROCESSING}

10 years record of rainfall, temperature and the remaining climatic data such as wind speed, sunshine hours and humidity data for the study area which is a secondary data were collected from the Ogun Osun River Basin Authority (ORBDA). In order to determine the basic hydrologic parameters, meteorological data was collected from the meteorological station.

The rainfall coefficient method (Daniel, 1974) was used to determine the monthly distribution of rainfall in the studied area and then to distinguish between rainy months and dry months. 


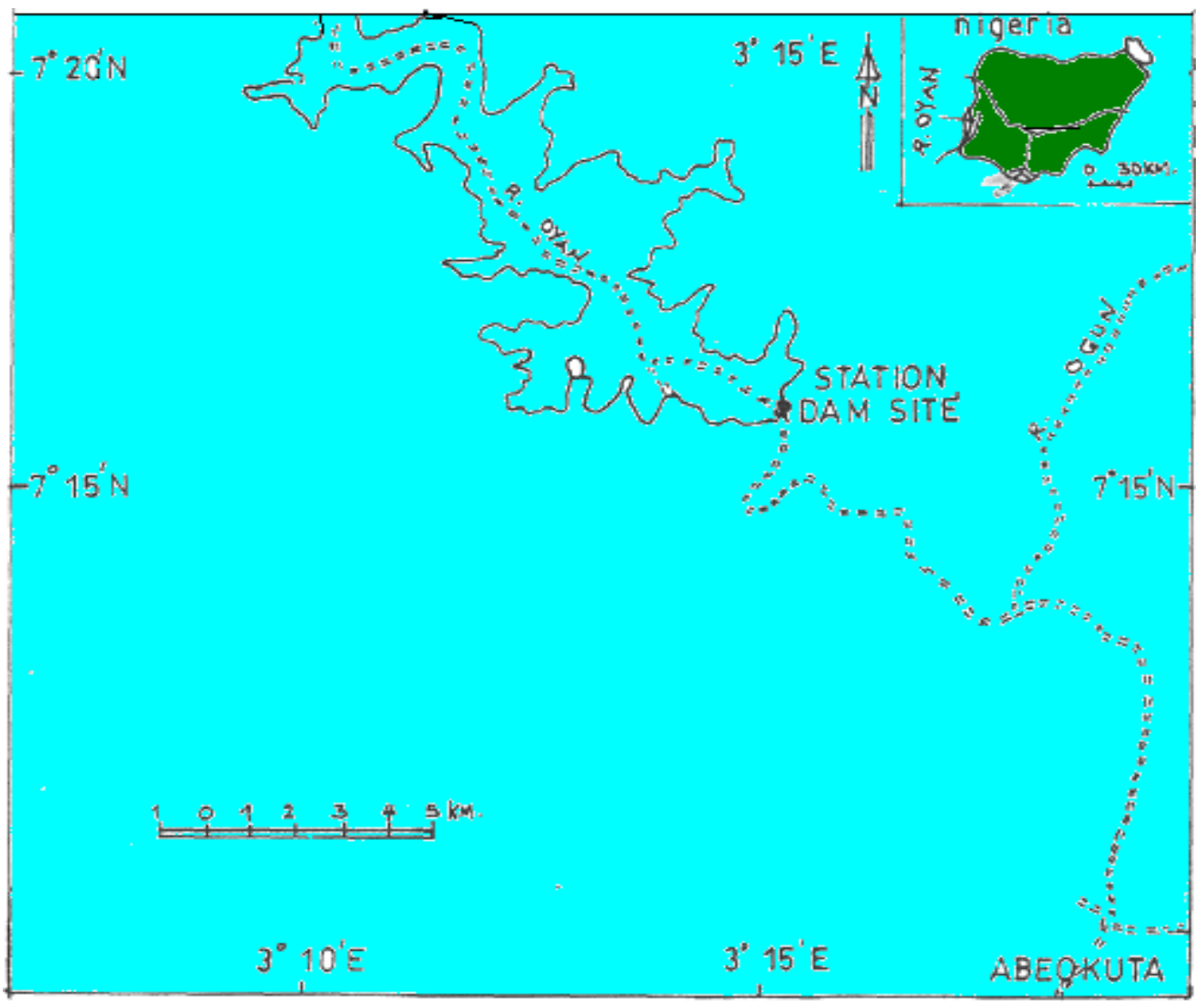

Fig. 1. Station Outline of Oyan River

Table 1. Classification scheme of monthly rainfall values

\begin{tabular}{ll}
\hline Designation & Rainfall Coefficient \\
\hline Dry month & Less than 0.6 \\
Rainy month & 0.6 and over \\
Small rains & $0.6-0.9$ \\
Big rains & 1 and over \\
Moderate concentration & 1 to 1.9 \\
High concentration & $2-2.9$ \\
Very high concentration & 3.0 and over \\
\hline \multicolumn{2}{c}{ Source: Daniel (1974). }
\end{tabular}

The spatial pattern of the seasonality of rainfall in the study area was determined by analyzing mean monthly rainfall data for the stations in the study area. To compare the 
monthly distribution of rainfall, the method of Daniel (1974) was adapted. This involved the calculation of "rainfall coefficient" for each month at each station, the coefficient being the ratio between the mean monthly rainfall and one-twelfth of the annual mean (the latter referred to as "rainfall module"). To distinguish between a "rainy" month and a "dry" month in the Awash Basin study, a month is designated "rainy" when the monthly rainfall coefficient reaches 0.6 ( $60 \%$ of the rainfall module), and distinctly rainy when it exceeds 0.8 . Extremely rainy months have a coefficient of more than 1 (i.e., the rainfall exceeds the module value) (Daniel, 1974).

In this study, a month is designated "rainy" if the rainfall coefficient is 0.6 or over. The term "small rains" is employed to refer to those months with a rainfall coefficient of 0.6 to 0.9 ; and the term "big rains" to those months where the coefficient is 1.0 and above. The "big" rainy months are further classified into three groups: those with "moderate concentration" of rainfall (coefficient of 1.0 to 1.9); those with "high concentration" of rainfall (coefficient of 2.0 to 2.9); and those with "very high concentration" of rainfall (coefficient of 3.0 and above).

In the catchment, pan evaporation data were not available, because of this, the Penman method was used to calculate the evaporation from the reservoir. Penman method was developed to calculate open water evaporation based on fundamental physical principles with empirical concepts incorporated to enable standard metrological observations to be used.

The Penman formula (Penman, 1948) for open water evaporation is:

$$
\mathrm{E} 0=(\Delta / \partial) \mathrm{H}+\mathrm{Ea} /(\Delta / \partial+1)
$$

Where,

E0 - open water evaporation in $\mathrm{mm} /$ day;

$\mathrm{H}$ - The available heat;

$\Delta / \partial$ - weighting factor (a function of temperature); and,

$\mathrm{Ea}$ - is to be determined empirically in ( $\mathrm{mm} /$ day).

The formula requires values of $\mathrm{H}$ and $\mathrm{Ea}$ as well as $\Delta / \partial$ for its application in the open water evaporation like Oyan reservoir.

$\mathrm{H}$ is calculated from incoming $\left(\mathrm{R}_{\mathrm{l}}\right)$ and outgoing (Ro) radiation determined from sun shine records, temperature and relative humidity using the following formula (Thornthwaite, 1948)

$$
H=\mathrm{RI}(1-\mathrm{r})-\mathrm{Ro}
$$

Where $r$ is the albedo and equals 0.05 for water.

The Thornthwaite method (Thornthwaite and Mather, 1957) was used to estimate the potential evapotranspiration of the catchment. This method uses air temperature as an index of the energy available for evapotranspiration, assuming that air temperature is correlated with the integrated effects of net radiation and other controls of evapotranspiration, and that the available energy is shared in fixed proportion between heating the atmosphere and evapotranspiration. There is no correction for different vegetation types. 
The Thornthwaite's empirical equation is:

$$
E=1.6\left(\frac{10 T n}{J}\right)^{a}
$$

Where,

$\mathrm{Et}=$ Potential evapotranspiration in centimeter per month .

$\mathrm{Tn}=$ Mean monthly air temperature $\left({ }^{\circ} \mathrm{C}\right)$.

$\mathrm{n}=1,2,3 \ldots 12$ is the number of the considered months.

$\mathrm{J}=$ Annual heat index and it is given by the equation:

$$
J=\sum_{n=1}^{12} \mathrm{j}
$$

$\mathrm{j}=$ is the monthly heat index and it is expressed as:

$$
j=\left(\frac{T n}{5}\right)^{1.514}
$$

$\mathrm{a}=0.49+0.0179 \mathrm{~J}-0.0000771 \mathrm{~J} 2+0.000000675 \mathrm{~J} 3$

Actual evapotranspiration data were not available in the stations employed in this study. Due to the almost complete lack of field instruments such as lysimeters, the Thornthwaite water balance model (Leopold and Dunne, 1978) was used to estimate the actual evapotranspiration in the study area. Through the calculation of an average water balance, actual evapotranspiration was estimated for the study area.

The volume of runoff $(Q)$ from the catchment area is computed by using the runoff coefficient method (Garg, 1987), which employed the following formula.

$$
Q=K \cdot P \cdot A \cdot m^{3}
$$

Where,

$\mathrm{K}$ is a constant also called runoff coefficient

$P$ is precipitation $(\mathrm{mm})$ : and,

$A$ is area of the basin $\left(\mathrm{m}^{2}\right)$.

The water balance for the study area was determined by using the following general water balance equation (Shaw 1994):

$$
P-E T-Q-1=0
$$

Where,

$\mathrm{ET}=$ Evapotranspiration

$\mathrm{I}=$ Infiltration

$\mathrm{P}=$ Precipitation

$Q=$ River discharge from the basin. 
The various assumptions made to derive the water balance equation for the study area are summarized below:

1. Since the computations are made on annual basis, net change of soil moisture and groundwater storage is assumed to be zero.

2. Subsurface water exchange with neighboring basins is assumed to be zero.

3. Assuming no artificial diversion from other basins.

\section{RESULTS AND DISCUSSION}

The result of the mean monthly rainfall averaged over the period of ten years is shown in Figure 3. The highest rainfall for the study area is recorded in June, July and September, which accounts about $47 \%$ of the total mean annual rainfall of the study area whereas the minimum rainfall is exhibited in December and January. The aerial pattern of the seasonality of rainfall in the study area is shown in Table 2. On the basis of this classification, as depicted in Table 3, the watershed is characterized by one rainy season during the year, i.e., at this station rainy months are not separated into more than one group of rainy months by dry months. There are two dry seasons during the year. The rainy season in total have eight months: March, April, May, June, July, August, September and October.

Table 2. Rainfall Coefficient and aerial pattern of the seasonality of rainfall in the study area

\begin{tabular}{|c|c|c|c|c|}
\hline Months & $\begin{array}{l}\text { Rainfall coefficient } \\
\text { values }\end{array}$ & Season & Classification & $\begin{array}{l}\text { Sub- } \\
\text { classification }\end{array}$ \\
\hline Jan & 0.00 & Dry & - & - \\
\hline Feb & 0.32 & Dry & & - \\
\hline Mar & 0.78 & Rainy & $\overline{\text { Small }}$ & \\
\hline Apr & 1.34 & Rainy & Big & $\bar{M}$ oderate \\
\hline May & 1.50 & Rainy & Big & Moderate \\
\hline Jun & 1.95 & Rainy & Big & Moderate \\
\hline Jul & 1.50 & Rainy & Big & Moderate \\
\hline Aug & 1.95 & Rainy & Big & Moderate \\
\hline Sep & 1.68 & Rainy & Big & Moderate \\
\hline Oct & 1.14 & Rainy & Big & Moderate \\
\hline Nov & 0.16 & Dry & 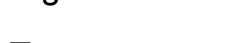 & \\
\hline Dec & 0.00 & Dry & - & - \\
\hline
\end{tabular}

The rains in March are small rain and accounts $6.5 \%$ of the average annual rainfall of the watershed. Big rains with moderate concentration occur in April, May, June, July, August, September and October and these accounts $89.5 \%$ of the average annual rainfall of the watershed. The amount of rainfall that occurs during the four months of dry seasons in total accounts for $4.0 \%$ of the average annual rainfall of the watershed. The study area has not experienced high and very high concentration of rainfall.

The result of the mean monthly temperatures over the period of ten years is shown in Figure 2. The mean annual minimum temperature of the study area is $26.7^{\circ} \mathrm{C}$ and the mean annual maximum temperature is $32.5^{\circ} \mathrm{C}$. The mean annual air temperature of the area is $30.7^{\circ} \mathrm{C}$. The mean monthly maximum and minimum temperature are observed in April and 
December, which are $35.2^{\circ} \mathrm{C}$ and $26.1^{\circ} \mathrm{C}$, respectively. The minimum air temperature is $29.7^{\circ} \mathrm{C}$ in August and the maximum air temperature is $31.2^{\circ} \mathrm{C}$ in May and June. The annual range of temperature is $1.5^{\circ} \mathrm{C}$.

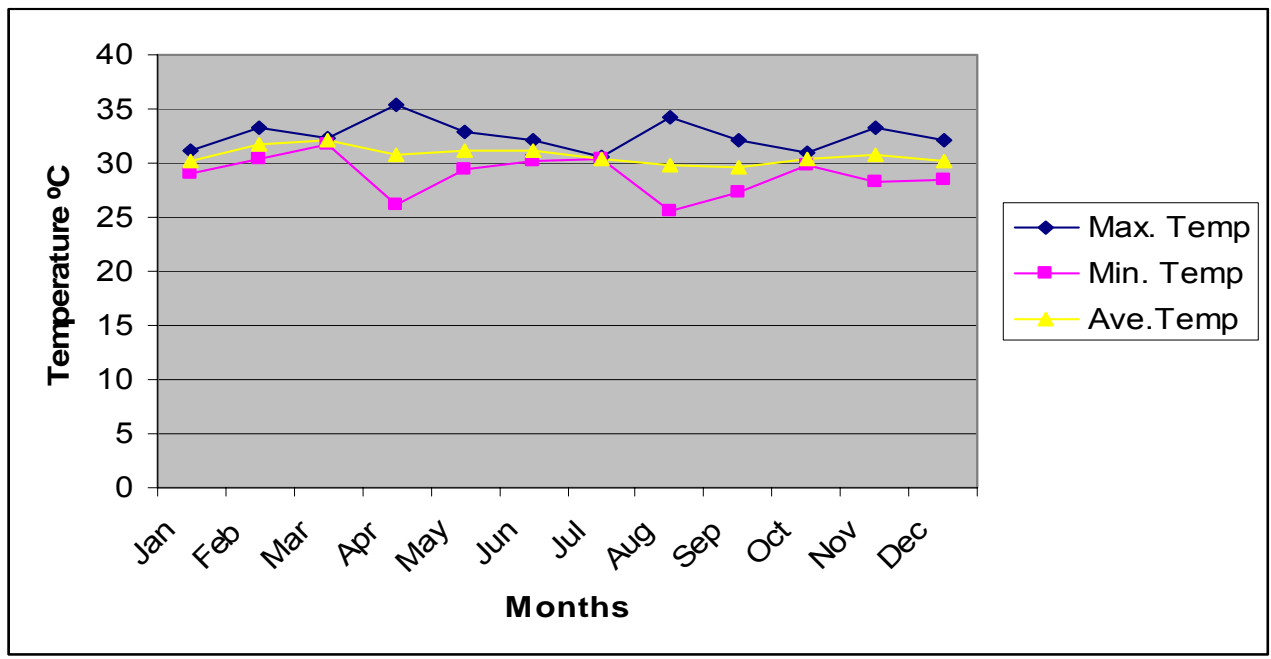

Figure 2: Mean monthly temperatures over the period of ten years (1994-2003) in the study area

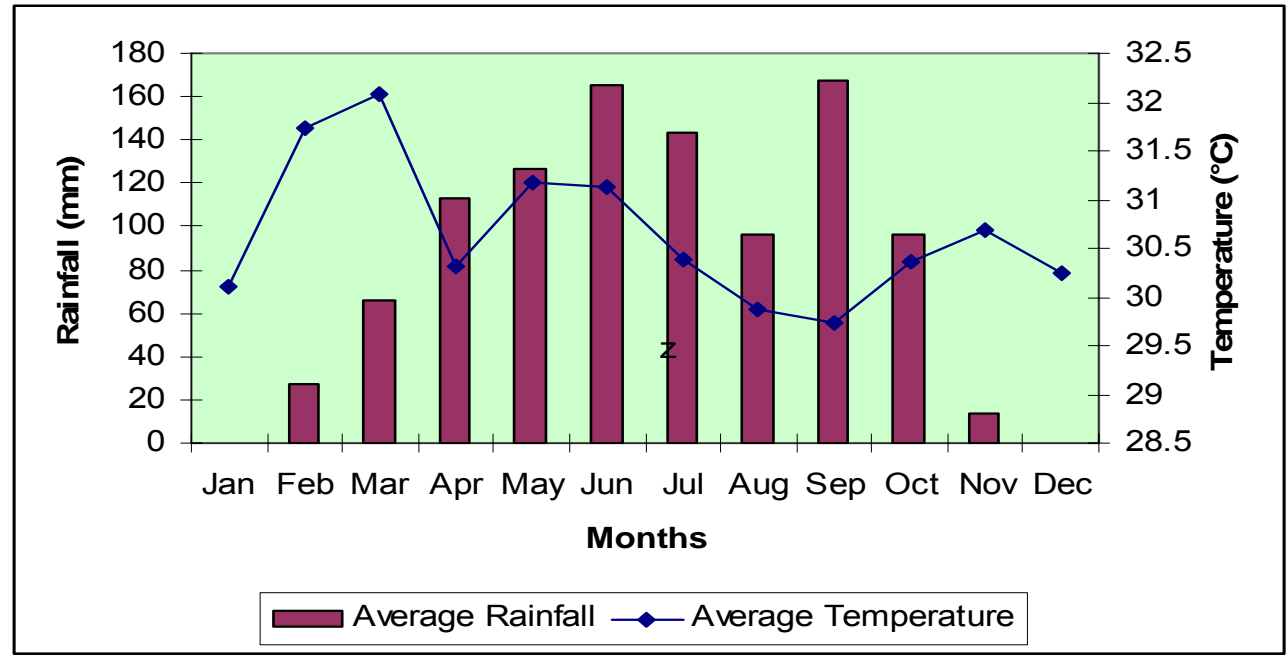

Figure 3: Rainfalls and temperature relationship over the period of ten years (1994-2003) in the study area

Figure 3 shows the temperature and rainfall relations over the period (1994-2003) for the study area. Even though the maximum temperature occurs only in April, high temperature values are observed during the rainy seasons. Months in the rainy seasons are warmer than months in dry seasons. The minimum temperatures as well as rainfall are also occurring almost in a similar range of months. 
The mean monthly wind speed values were computed and are given in the Table 3 below. The maximum and minimum wind speed value is obtained in March $(0.46 \mathrm{~m} / \mathrm{s})$ and November $(0.16 \mathrm{~m} / \mathrm{s})$, respectively. In general the highest wind speed values are found both in the rainy months where rains are occur in moderate concentration.

Table 3: Mean monthly wind speed in the study area

\begin{tabular}{lllllllllllll}
\hline Months & Jan & Feb & Mar & Apr & May & Jun & Jul & Aug & Sep & Oct & Nov & Dec \\
\hline $\begin{array}{l}\text { WS } \\
\text { (m/s) }\end{array}$ & 0.35 & 0.43 & 0.46 & 0.44 & 0.36 & 0.38 & 0.32 & 0.30 & 0.28 & 0.19 & 0.16 & 0.17 \\
\hline WS: Wind speed & & & & & & & & & & & &
\end{tabular}

The result of the mean monthly relative humidity (\%) values is computed in the Table 4 below. The maximum and minimum relative humidity value is found in July (89.5\%) and March (74.2\%), respectively. In general the highest humidity values are found in the rainy months whereas the lowest values are in dry months.

Table 4: Mean monthly relative humidity (\%) in the study area

\begin{tabular}{lllllllllllll}
\hline Months & Jan & Feb & Mar & Apr & May & Jun & Jul & Aug & Sep & Oct & Nov & Dec \\
\hline RH (\%) & 78.3 & 79.1 & 74.2 & 83.7 & 84.8 & 85.9 & 89.5 & 88.1 & 88.0 & 86.4 & 82.1 & 77.4 \\
\hline
\end{tabular}

RH: Relative humidity

The result of the mean monthly sunshine hours of the area is given in the Table 5 below. The maximum sunshine hour is recorded in October (6.6 hours) whereas the minimum one is in August (2.5 hours). Generally, the maximum sunshine hours are found in dry months whereas the minimum are in very highly rainy months.

Table 5: Mean monthly sunshine hours in the study area

\begin{tabular}{lllllllllllll}
\hline Months & Jan & Feb & Mar & Apr & May & Jun & Jul & Aug & Sep & Oct & Nov & Dec \\
\hline SH (hrs) & 6.35 & 5.0 & 5.18 & 4.8 & 5.6 & 4.9 & 3.7 & 2.5 & 2.9 & 6.6 & 6.5 & 6.2 \\
\hline
\end{tabular}

SH: Sunshine hours

The result of the mean monthly evaporation from the Oyan reservoir is shown in Table 6. The result showed that the total annual water loss by evaporation is $1178.5 \mathrm{~mm}$. In order to find the volume of water lost by evaporation from the reservoir, the mean annual evaporation, $1715.3 \mathrm{~mm}$, was multiplied by the total area of the reservoir, which is $40 \mathrm{~km}^{2}$ and was found to be 47.1 million cubic meters. The highest value of evaporation was in month March in which the temperature starts to be higher. The table below shows the total mean annual evaporation loss. 
Table 6. Evaporation from the Oyan Reservoir

\begin{tabular}{|c|c|c|c|c|c|c|c|c|c|c|c|c|c|}
\hline Months & Jan & Feb & Mar & Apr & May & Jun & Jul & Aug & Sep & Oct & Nov & Dec & $\begin{array}{l}\text { Mean } \\
\text { Annual }\end{array}$ \\
\hline $\mathrm{H}$ & 5.55 & 5.6 & 5.81 & 5.96 & 5.82 & 5.41 & 5.11 & 4.85 & 5.01 & 6.24 & 5.9 & 5.37 & \\
\hline $\mathrm{Ea}$ & 2.48 & 2.83 & 3.24 & 2.17 & 1.69 & 1.51 & 1.02 & 1.21 & 1.24 & 1.39 & 1.98 & 2.42 & \\
\hline$\Delta / \partial$ & 3.17 & 3.51 & 3.34 & 3.69 & 3.17 & 3.01 & 3.01 & 3.01 & 3.01 & 3,17 & 3.34 & 3.34 & \\
\hline Eo & 86.6 & 89.6 & 109.6 & 108.2 & 115.9 & 106.6 & 101.0 & 94.6 & 85.5 & 106.7 & 89.8 & 84.4 & 1178.5 \\
\hline
\end{tabular}

Where $\mathrm{H}$ - The available heat; Ea- is to be determined empirically in ( $\mathrm{mm} /$ day); / - weighting factor (a function of temperature);

Eo - open water evaporation in $\mathrm{mm}$

Table 7. Potential Evapotranspiration from the Oyan Catchment

\begin{tabular}{llllllllllllll}
\hline Month & Jan & Feb & Mar & Apr & May & Jun & Jul & Aug & Sep & Oct & Nov & Dec & Annual \\
\hline PET & 89.8 & 92.7 & 109.3 & 105.4 & 121.8 & 121.1 & 118.9 & 117.7 & 103.7 & 103.2 & 90.1 & 89.3 & 1261.0 \\
\hline
\end{tabular}

Table 8. Average monthly water balance at the catchment

\begin{tabular}{|c|c|c|c|c|c|c|c|c|c|c|c|c|c|}
\hline Months & Jan & Feb & Mar & Apr & May & Jun & Jul & Aug & Sep & Oct & Nov & Dec & Annual \\
\hline$P$ & 0.00 & 26.97 & 66.05 & 113.2 & 126.9 & 165.1 & 142.9 & 96.52 & 167.6 & 96.04 & 13.59 & 0.00 & 1015.09 \\
\hline PET & 89.8 & 92.7 & 109.3 & 105.4 & 121.8 & 121.1 & 118.9 & 117.7 & 103.7 & 103.2 & 90.1 & 89.3 & 1261.0 \\
\hline P-PET & -89.8 & -65.7 & -45.3 & -7.8 & 5.1 & 44.0 & 24.0 & -21.2 & 63.9 & -7.16 & -76.5 & -89.3 & -265.8 \\
\hline APWL & -262.8 & -328.46 & -373.8 & -381.6 & & & & & & -7.16 & -83.7 & -172.9 & \\
\hline SM & 95 & 80 & 83.14 & 102.06 & 114.5 & 166.87 & 200 & 200 & 200 & 196.0 & 170.0 & 110.0 & \\
\hline$\Delta \mathrm{SM}$ & -15 & -15 & 3.14 & 18.92 & 12.44 & 52.37 & 0.00 & 0.00 & 0.00 & -4.00 & -26.0 & -60.0 & \\
\hline AET & 53.9 & 55.6 & 76.5 & 73.7 & 97.4 & 96.9 & 95.1 & 94.2 & 75.6 & 72.7 & 54.1 & 53.6 & 899.3 \\
\hline
\end{tabular}

$P=$ precipitation; $P E T=$ potential evapotranspiration; $P-P E T=$ the difference between precipitation and potential evapotranspiration; $A P W L=$ accumulated potential water deficit, Sum of negative values of p-pet; $S M=$ soil moisture; $\triangle S M=$ change in soil moisture; $A E T=$ actual evapotranspiration 


\section{Evapotranspiration from the Catchment}

The result of the mean monthly evapotranspiration from the catchment is shown in Table 7 . From the table, evapotranspiration of the study area was estimated to be $1261.0 \mathrm{~mm}$ and through the calculation of an average water balance, actual evapotranspiration was estimated for the study area.The mean annual actual evapotranspiration of the catchment and the command area is $899.3 \mathrm{~mm}$.

\section{Runoff for the catchment}

The runoff for the catchment is given by,

$$
Q=K \cdot P \cdot A \cdot m^{3}
$$

Where

$Q$ is the runoff from the upper catchment

$\mathrm{A}$ is the area of the catchment $\left(9000 \mathrm{~km}^{2}\right)$;

$\mathrm{P}$ is the mean annual precipitation $(1015.1 \mathrm{~mm})$; and,

$\mathrm{K}$ is runoff coefficient which is 0.09

Accordingly, the mean annual runoff generated from the catchment is estimated to be 822.2 million cubic meters.

\section{Water Balance}

The result of the water balance from the study area based on the various assumptions that since the computations are made on annual basis, net change of soil moisture groundwater storage is assumed to be zero. Subsurface water exchange with neighboring basins is assumed to be zero and assuming no artificial diversion from other basins (Table 8).

Precipitation is the only input component to the effective watershed area whereas evapotranspiration, runoff and the water that is lost by infiltration are on the output side.

From the budget equation, the amount of water that percolates into the ground in the catchment as a groundwater accretion has been calculated as follows:

Ac $=$ Area of the catchment $=9000$ sq. $\mathrm{km}$;

$\mathrm{AET}=8093.7 \times 10^{6} \mathrm{~m}^{3}$;

$\mathrm{P}=9135.8 \times 10^{6} \mathrm{~m}^{3} ;$ and,

$\mathrm{Q}=822.2 \times 10^{6} \mathrm{~m}^{3}$

Therefore,

$\mathrm{I}=[(9135.8-8093.7-822.2)] \times 106 \mathrm{~m}^{3}$

$=219.910^{6} \mathrm{~m}^{3}$

\section{Water Loss by Infiltration at the Reservoir}

Precipitation and runoff from catchment are the input components to the reservoir whereas evaporation from the reservoir, infiltration into the groundwater constitutes the output components. The amount of water that percolates into the ground at the reservoir site as a groundwater accretion has been calculated as follows. 
As $=$ Area of the reservoir $=40$ sq. $\mathrm{km}$;

$E=$ Evaporation from the reservoir $=35.9 \times 10^{6} \mathrm{~m}^{3}$;

$\mathrm{P}=40.6 \times 10^{6} \mathrm{~m}^{3}$

$\mathrm{Q}==822.2 \times 10^{6} \mathrm{~m}^{3}$.

Therefore,

$I=\left[(40.6+822.2-35.9] \times 10^{6} \mathrm{~m}^{3}\right.$

$=826.9 \times 10^{6} \mathrm{~m}^{3}$

As shown above, the recharging capacity of the reservoir is larger than the catchment. Thus, the total infiltration in the Oyan catchment is 1046.8 million cubic meters.

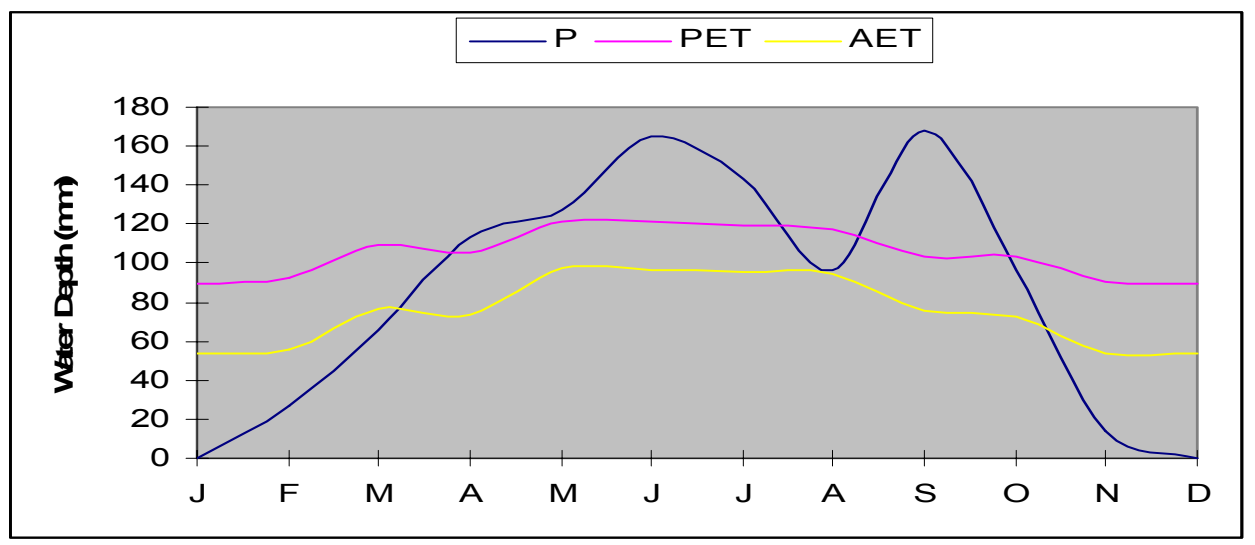

Fig. 4. Average Water Balance for the Study Area

\section{DISCUSSION}

The amount of rainfall does not only vary from month to month but it also shows fluctuation from year to year. The highest rainfall for the study area is recorded in June, July and September and the amount of rainfall in January and December is virtually low.

The variation in the seasonal distribution of rain fall is attributed to the position of the InterTropical Convergence Zone (ITCZ), the relationship of between upper and lower air circulation, the effects of topography and the role of local convection currents and the amount of rainfall (Kebede, 1964; Daniel, 1977). It is noted that the trend of rainfall is low in August as a result of the August Break and rainfall reaches its maximum in September. There are two rainy seasons during the year. The rainy season in total have eight months: March, April, May, June, July, August, September and October.

Small rains are experienced in March while big rains with moderate concentration are experienced in April, May, June, July, August, September and October and these accounts $89.5 \%$ of the average annual rainfall of the watershed.The study area has not experienced high and very high concentration of rainfall. 
Months in the rainy seasons are warmer than months in dry seasons (Nata et al., 2010). The highest temperature value is observed during the dry season while the highest wind speed values are found both in the rainy months where rains are occur in moderate concentration.

Similarly, the highest humidity values are found in the rainy months whereas the lowest values are in dry months while the maximum sunshine hours are found in dry months whereas the minimum are in very highly rainy months. When the Sunshine is at its peak, the relative humidity is extremely low in the dry season and vice versa in the rainy season.

The trend of evaporation is similar to that of the precipitation and the highest value of evaporation was in month March in which the temperature starts to be higher.

The highest monthly values of potential evapotranspiration in the basin in general come just before the onset of the rainy season; and lowest values during the rainy season, when the cloud cover reduce air temperatures. Actual evapotranspiration data are not available in the stations employed in this study.

The flow of any stream is determined by climatic factors (particularly precipitation) and the physical characteristics of the drainage basin. The latter includes land use, type of soil, type of vegetation, area, shape, elevation slope, orientation, type of drainage network, extent of indirect drainage and artificial drainage (Wisler and Bater, 1959; Ward, 1967; Fetter, 1988). Since there were no water level observations and flow measurements conducted in the study area due to lack of hydrometric station in any one of the rivers in the area, it was impossible to analyze the runoff of the area by computer models or scale models. Other methods like the unit hydrograph and flood frequency analyses were also not used because of their requirements of historical records. The mean annual runoff generated from the catchment is about $10 \%$ of the total rainfall, though Ward and Robinson (1990) found that increase in the magnitude of peak flows, below large urban areas, is the results of an increase in the volume of quick flow and more rapid movement of runoff, which is possible in urbanized areas. Moreover, as a consequence of the above mentioned factors, poor and limited drainage system and lack of flood control mechanisms have resulted in temporary flooding of the area adjoining the river. The variation in annual flow is due to changes in the climatic condition of the basin in particular and the country in general. The great variation in flow from one season to another mainly reflects the climatic conditions, i.e. seasonality of rainfall and amount of evapotranspiration in the basin.

Usually, the net runoff component will not be an important quantity (except in the cases of intense storms) until most of the soil moisture deficit has been replenished. After the soil has more or less been filled to the storage capacity, the surface runoff increases quite rapidly and will represent a large and fairly constant percentage of precipitation during the storm. The groundwater runoff on the other hand represents the main long term component of the net runoff and may be of particular significance during the long spells when rainfall and consequently surface runoff are totally absent.

Based on the various assumptions that since the computations are made on annual basis, net change of soil moisture and groundwater storage is assumed to be zero. Subsurface water exchange with neighboring basins is assumed to be zero and assuming no artificial diversion from other basins, Precipitation is the only input component to the effective watershed area whereas evapotranspiration, runoff and the water that is lost by infiltration are on the output side for water loss by infiltration in the catchment while precipitation and runoff from catchment are the input components to the reservoir whereas evaporation from 
the reservoir, infiltration into the groundwater constitutes the output components for water loss by infiltration at the reservoir. In general, the catchment has very good groundwater potential, if it is developed and utilized properly.

\section{CONCLUSION}

The study area receives a mean annual rainfall of $1015.09 \mathrm{~mm}$. The highest rainfall of the area is recorded in June, July and September, which accounts about $47 \%$ of the total mean annual rainfall of the study area whereas the minimum rainfall is exhibited in December and January. The watershed is characterized by two rainy season during the year, i.e., at this station rainy months are not separated into more than one group of rainy months by dry months. The rainy season in total have eight months: March, April, May, June, July, August, September and October.

Even though the maximum temperature occurs only in April, high temperature values are observed during the rainy seasons. Months in the rainy seasons are warmer than months in dry seasons. The minimum temperatures as well as rainfall are also occurring almost in a similar range of months. . In general the highest speed values are found both in the rainy months where rains are occur in moderate concentration, the highest humidity values are found in the rainy months whereas the lowest values are in dry months and the maximum sunshine hours are found in dry months whereas the minimum are in very highly rainy months. The total annual water loss by evaporation is $1178.5 \mathrm{~mm}$ while the method the mean annual potential evapotranspiration of the study area is $1261.0 \mathrm{~mm}$.

The mean annual actual evapotranspiration from the catchment is $56.2 \%$ of the mean annual rainfall that occurs on it.

The mean annual runoff generated from the catchment is $15 \%$ the mean annual surplus, which is available for both infiltration and runoff in the catchment. At the reservoir site the amount of water that percolates down at the base of the reservoir is 826.9 million cubic meters. The total amount of water which is actually available to recharge the groundwater circulation within the oyan catchment is 1046 .8million cubic meters.

The determination of the components of the water balance has a great contribution in the water budgeting. A water resources development program that is carried out on the basis of this water budget information will definitely minimize risk and mismanagement, and hence will led to a proper utilization of this precious resource. Storage of surface water is a central strategy in guaranteeing water supply in some regions. The results reported here confirm the significant impact of water retention in reservoirs on the water balance of the Oyan Lake. They show that the total impact is often considerably greater than the volumes extracted for water use, due to the large amount of losses by evaporation. The latter is the price to be paid by fulfilling water demand from surface-water storage facilities. As a consequence, water balances of reservoirs can only be simulated realistically in direct link with simulations of water use and discharge routing through the river network and the multiple-reservoir systems, including spatially explicit information on runoff generation along the river system. The relevance of a direct coupling becomes obvious for all locations receiving inflow from upstream areas, where this inflow depends on the upstream reservoir water balance. 


\section{REFERENCES}

Daniel, G. (1974). Aspects of climate and water budget in Ethiopia. Addis Ababa Addis Ababa University Press.

Daniel, G. (1977). Aspects of Climate and Water Budget in Ethiopia. A Technical Monograph Published For Addis Ababa University. Addis Ababa University Press.

Fetter, C.W. (1988). Applied Hydrogeology. Prentice Hall, Upper Saddle River, New Jersey.

Garg, K. (1987). Irrigation engineering and hydraulic structures. India: Khanna Publishers.

Geiger, K.W., Hitchon, B. (1964). Ground water measurement. In: Proc. Hydrology Symposium, No. 4, pp. 245-265. Victoria, National Research Council of Canada.

Johnson, P.A., Curtis, P.D. (1994). Water Balance of Blue Nile River Basin in Ethiopia. J. Irrig. Drain. Engg., 120, 573-589.

Kebede, Tsehayu, Tadesse, H. M. (1964). Engineering Geological Mapping of Addis Ababa. Ethiopian Institute of Geological Survey. Addis Ababa.

Leopold, L.B., Dunne, T. (1978). Water in Environmental Planning. W.H. Freeman and Company, New York. Nata, T., Shishay, T., Mekdes, T. (2010). The Water Balance of May Nugus Catchment, Tigray, Northern Ethiopia, Agricultural Engineering International: CIGR Ejournal. Manuscript 1306. Vol. XII.

Ofoezie, J.E, Imevbore, A.M.A, Balogun, M.O, Ogunkoya, O.O, Asaolu, S.O. (1991). A study of an outbreak of Schitosomiasis in two resettlement villages near Abeokuta, Ogun State, Nigeria. J. Helminthol., 65, 95-102.

Ogun Osun River Basin Development Authority. (1997). Brief on the activities of OORBD-A (1977-1996). OORBD-A Flyer March 1997. Ogun Osun River Basin Development Authority (1998) (O-ORBDA). What it is, what it does, how it works. O-ORBDA 5 pp.

Penman, H.L. (1948) Natural evaporation from open water, bare soil and grass. Proc. Roy. Met. Soc. (A), no. 193, 120-145.

Prasad, T. (1982) Potential for economic transformation of a poor region through water resources development. Wat. Int., 7(3), 117-122.

Ritter, M.E. (2006). The Physical Environment: an Introduction to Physical Geography.

Shaw, M. (1994). Hydrology in practice. Van Nostrand Reinhold. Berkshire, UK, 245pp.

Thornthwaite, C.W. (1948). An approach towards a rational classification of climates. Geogr. Rev., 38, 55-94.

Thornthwaite, C.W., Mather, J.R. (1957) Instructions and tables for computing Potential evapotranspiration and the water balance. New Jersey: Publication in Climatology Center ton, X, No3, pp. 185-204.

UNESCO. (1974). Methods for Water Balance Computations. Paris: Beugnet, pp. 1-127.

Ward, R., Robinson, M. (1990). Principles of Hydrogeology. Third Edition. McGraw-Hill Book Company. UK.

Wisler, C., Brater, E. (1959). Hydrogeology. Second Edition. John Welly and Sons Inc., Japan.

(C) 2011 Ufoegbune et al.; This is an Open Access article distributed under the terms of the Creative Commons Attribution License (http://creativecommons.org/licenses/by/2.0), which permits unrestricted use, distribution, and reproduction in any medium, provided the original work is properly cited. 